\title{
Trypsin and Trypsinogen Measurement
}

National Cancer Institute

\section{Source}

National Cancer Institute. Trypsin and Trypsinogen Measurement. NCI Thesaurus. Code C135450.

The determination of the amount of the total trypsin and total trypsinogen in a biological specimen. 